\title{
Vertical and Shared Leadership as Predictors of Team Effectiveness: Insights from Healthcare Sector in a Developing Country
}

\author{
Mirko Perano ${ }^{1}$, Xhimi Hysa ${ }^{2}$, Drinalda Durmishi ${ }^{3} \&$ Bice Della Piana $^{4}$ \\ ${ }^{1}$ Department of Management, Reald University College, Vlorë, Albania \\ ${ }^{2}$ Department of Business Administration, Epoka University, Tirana, Albania \\ ${ }^{3}$ Department of Accounting, Turgut Ozal Colleges, Tirana, Albania \\ ${ }^{4}$ Department of Management \& Innovation Systems, University of Salerno, Italy \\ Correspondence: Mirko Perano, Department of Management, Reald University College, Vlorë, Albania. E-mail: \\ mirko.perano@unireald.edu.al
}

Received: June 15, 2019

doi:10.5539/ijbm.v14n8p52
Accepted: June 30, 2019

Online Published: July 7, 2019

URL: https://doi.org/10.5539/ijbm.v14n8p52

\begin{abstract}
Team effectiveness is the result of teamwork, with teams scoring high in job performance, job satisfaction, and team viability. In healthcare, teamwork is decisive for the well-being of patients and their satisfaction. Among the scholars, there is an ongoing debate about the best leadership approach to maximize team effectiveness. In this paper, we start from the seminal work of Pearce \& Sims (2002) that investigates vertical versus shared leadership as predictors of the effectiveness. Team effectiveness has been analyzed according the constructs of team processes and performance. The vertical/shared leadership have been analyzed from their main constructs: vertical/shared transactional leadership, vertical/shared transformational leadership, and vertical/shared empowering leadership. Differently from Pearce \& Sims (2002), this study was conducted in the healthcare sector of a developing country. Data was collected from a questionnaire distributed to 17 public and private healthcare teams as assessed from two sources: team leaders and team members. The sample was composed of 138 participants from the healthcare personnel, distributed in 17 diverse teams. From literature six hypotheses has been developed and descriptive and inferential statistics are also provided. Team effectiveness was found to be significantly predicted by both vertical leadership and shared leadership. The shared leadership was found to be significant predictor of team effectiveness in all its three constructs (transactional, transformational, and empowering shared leadership), whereas the vertical leadership was found to be significant predictor of team effectiveness in only two constructs (transformational and empowering vertical leadership). Theoretical and practical implications for managers in healthcare sector are also provided.
\end{abstract}

Keywords: shared leadership, vertical leadership, team effectiveness, healthcare, strategy, developing country

\section{Introduction}

In the last century, the leadership has captured the attention of both academics and managers. A reason can be found in "the nature of the complexity of this process" (Jones \& Kriflik, 2006, p. 158; Rost, 1993). From the academic point of view, eminent names such as Max Weber, Chester Barnard and Philip Selznick provided their common thinking well synthetized by Podolny et al. (2005): they "believed that one could not fully understand what those in organizations believe or how they behave without reference to the presence (or absence) of organizational leaders" (p. 2). Leadership is a process, not a position (Parry, 1999). It is usually analyzed within psychological perspective as: a process of psychological (Pucic, 2011, 2015) and social (Parry, 1998; Chemers, 1997, 2000, 2003) influence; a psychological characteristic of human beings (Zwartjes et al., 2012; Van Langenhove et al., 2016) or a social psychological phenomenon (Hogg et al., 2005), in which the main actors are: a leader and the followers in a formal or informal organization. According to Kotter (1990; 1990a), the successful leader "creates vision and strategies" (1990a, p. 36) not the plan; these can be seen as the result of a systemic view of several elements such as an organization, a corporate culture, a business, a technology or an activity (Kotter 1990a). So, leadership can be seen as "a label that followers confer on the leader" (Pucic, 2015, p. 658).

This work addresses the effect of vertical and shared leadership to team effectiveness in the healthcare sector. 
Studies about shared leadership in healthcare have already been performed previously (Nielsen et al., 2009; Jackson, 2000; Konu \& Viitanen, 2008; Merkens \& Spencer, 1998; Spooner et al., 1997; Steinert et al., 2006). We cannot state the same for studies about vertical leadership, or even less for studies combining both vertical and shared leadership in healthcare. Previous research about the combination of vertical and shared leadership as applied to team effectiveness, besides being limited and not exclusively applied to healthcare, already exists. For instance, eminent researchers for this purpose like Pearce \& Sims (2002) have investigated vertical versus shared leadership as predictors of the effectiveness of change management teams. Nevertheless, their research was applied to automotive industry in a major country and not to the healthcare sector in a developing country.

Hence, in this study we propose a combined analysis of both vertical and shared leadership in the healthcare sector to understand how team effectiveness is influenced. The research context in here is Albania, and this is a pioneer research for Albania and Western Balkans. Stemming from Pearce \& Sims (2002) that introduced five types of leader behavior - aversive leadership, directive leadership, transactional leadership, transformational leadership, and empowering leadership - in this work we focus our attention on transactional, transformational, and empowering leadership. In order to get a closer view to the extent of the research, there have been explained the representative behaviors of the three leadership types as based on the theory. By using comparative statistics, team effectiveness was found to be significantly predicted by the vertical transformational leadership and the vertical empowering leadership, but not by the vertical transactional leadership. Meanwhile, team effectiveness was found to be significantly dependent on three constructs of shared leadership: shared transactional leadership, shared transformational leadership, and shared empowering leadership.

\section{Theoretical Background}

\subsection{Leadership: from Conceptualization to Collaborative Actions}

Leadership is a fundamental issue that affects the success and failure of every organization or country (Kocolowski, 2010); is a process whereby an individual influences a group of individuals to achieve a common goal (Northouse 2013). From the beginning of the twentieth century for around 90 years on, studies revealed more than 200 different definitions of leadership (Northouse 2013). Leadership scholars themselves likely-mindedly agree that leadership cannot be defined (Podolny et al., 2005). There are different reasons for this such as the effects of growing global influences, generational differences that will arouse different meanings of leadership in different people. In addition, Stodgill (1974) in a leadership review points out that there are as many different definitions of leadership as the people trying to define it. He puts leadership besides notions like peace and democracy even though we intuitively know what we mean by these words, the words can have different meanings for different people. Rost (1991) studied the evolution of leadership definitions from 1900 until 1990s. He found that the concept of leadership during the '50s is the closest one to today's mentality. In the ' 50 s, the continuance of group theory is first theme of leadership. Later, leadership is seen as a relationship that develops shared goals. The last theme is the effectiveness, which shows the abilities of the leader to influence the group. Deriving from this study, Rost (1991) conceptualizes leadership as an influence relationship among leaders and followers who perform real changes that reflect their mutual purposes. Based on Rost (1991), Block (2003) defines leadership as an influence relation that is multidirectional within a group, meaning that influence flows in all directions not just from the top to subordinates (Rost, 1991; Block, 2003; Bennett et al., 2003 from Harris, 2004). Moreover, this is the advantageous difference between shared leadership and classic perceptions of leadership (Pearce et al., 2009). At the same time, this relationship is characterized by behaviors that are persuasive as opposed to dictatorial. Studies performed in companies offering public services in different areas (catering, education sector) have revealed that teamwork and shared leadership have amplified the individual talent of a leader. Concentrating on the leading indicators of success (client satisfaction and workmate development) has resulted in good performance of the company (Pearce et al., 2009). Block (2003) considers the followers as active participants in the relationship, and they are engaged in leadership as leaders do. This relation is described in a harmonic way where both parts are interested in performing real change, working to pursue mutual purposes who lead on the shaping of a common mission. Similarly, Krishnan (2003) points out that leadership is inducing followers to pursue common or at least joint purposes that represent the values and motivations of both leaders and followers. Organizations have already widely accepted that leadership is not merely a technical occupation, but that it includes the managing of people, establishing and developing the sense of community within the organization (Brown, 1992; Conger, 1993). A study in healthcare revealed that involvement of nurses in decision making (concerning euthanasia-related issue) has gained broad support from nurses themselves (Inghelbrecht et al., 2009). Nurses are the largest workforce near to the service receivers and assessing their opinions regarding the usefulness of the immunization program in the scope of public health has been helpful in the functioning of this program (Gilca et al., 2009). Leadership is no longer seen as a function of 
position or authority. It is fundamentally a 'social good' (Canadian Health Leadership Network, 2014).

Through the decades of the 20th century, we see the definitions furthermore detailed and developed. In the 21st century, the leadership scholars agree on the impossibility of defining the leadership. Again, Northouse (2013) expresses that leadership can be described and conceptualized.

Leadership is an important subject of study in organizations involved in public service such as education and health. Healthcare is a sector with very complex problems and dynamics and there is no more the idea of the "heroic" leader ready to solve every problem, but collaboration is necessary. In the last decade, many scholars have made significant endeavors in research on health leadership (Avolio et al., 2009).

\subsection{Vertical Leadership vs Shared Leadership}

The classical and traditional perspective on leadership has been that of sees leadership as a "solo dance" where the leader, central character of Great Man theories, is the person who has some remarkable and unreplaceable traits with which can enable him/her to direct the orchestra and the audience. This is in contrast with contemporary approaches that instead of focusing on personal traits are more oriented toward focused on leadership behaviors. These leader's behaviors both condition and are conditioned by those of followers. As a result, the "solo dance" is replaced by the "dancing relationship" between leaders and followers that reciprocally influence each other. The direction and intensity of influence is context-specific. Thus, the absolutism of "one-man-show" is substituted replaced by the relativism of the relations. The point is: what type of relations?

Vertical leadership evokes simultaneously a top-down approach (direction) and a bottom-up approach (development). In other words, the game' rules are provided by the team leader and these addresses origins from its influence and derived from the power of his/her position. According to Yukl (1998), the vertical leadership implies the definition of heroic leadership. The hero guides or develops his pupils. Through a developmental perspective, Petrie (2014) relies on coaching by considering the word "vertical" as synonymous with progress and leadership development. Vertical leadership research is consolidated with studies that have identified and validated several types of leader behaviors (Bass, 1990; Yukl, 1998). From the innovativeness viewpoint and from the perspective of current business dynamics, vertical leadership, although still useful in practice, is not appealing anymore when it comes to theory. Environmental complexity, technological progress, Internet of Things, Industry 4.0 etc., are transforming organizational structures into flat ones, with less bureaucracy and more self-managing teams for quick response and adaptation toward the dynamic environment. During the self-managing process team members are reciprocally influenced for achieving the goals. This lateral and distributed influence among peers from within the team defines what today is called shared leadership, with particular consequences on team dynamics and effectiveness (Avolio et al., 1996; Pearce \& Conger, 2003; Pearce \& Sims, 2002; Yukl, 1998).

Within the team leading processes, shared leadership brings out the agentic role of the team (Nicolaides et al., 2014; Zhu et al., 2018). Shared leadership presence is crucial among healthcare sectors and it should foster new collaborations among individuals who support and manage the research and those who provide, and the ones who receive care (Dougherty \& Conway, 2008). Lovelace et al. (2007) suppose that shared leadership practices can help leaders manage high job demands and rise long-term job control. In their work they study work stress and leadership development, and referring to Hambrick et al. (2005), and to Sparks et al., (2010), they state that while all employees undergo work stress, leaders tend to have particularly stressful jobs due to the high levels of demands and responsibilities related to the leadership position. Accordingly, the researchers emphasize that preparing leaders to manage work stress is an important component of leadership development. Moreover, in order to treat this critical issue, we see that researchers examine the problem by integrating work stress and selfand shared leadership (Lovelace et al. 2007). By the means of sharing leadership, much of the workload that can lead to stress from being overwhelmed on the job can be cleared off (Pearce \& Conger, 2003). Furthermore, by emboldening the capacity of followers to some extent to be their own leaders, the potential stress of leadership responsibility can be decreased (minimized) over time (Manz \& Sims, 2001). Leadership gets an empowered view with the fact that different people amongst a work unit can share it. The aim to reach the common goals that have been established by the members of a group or organization becomes more easily realized by interactive and dynamic influence process among the members of the group. This process is the one to be referred as shared leadership (Pearce \& Conger, 2003). Pearce (2007), by referring to Lovelace, et al., (2007) concerning shared leadership for stress management, considers the shared leadership as a treatment cure for the stress that might affect the work performance.

Zho et al. (2018) provide a review of the growing literature about shared leadership from which key characteristics have been identified (tab. 1). 
This study aimed at finding the effect of shared leadership in team effectiveness. Furthermore, in the health sector the effectiveness is expected to enhance the patient satisfaction.

Hierarchical structures in the organizations are being replaced by structures based on "team" concept and consequently shared leadership is coming forward in the observations of the researchers (Avolio et al., 2009). Other healthcare studies have come to a decision that working with the sense of a team decreases the intensity of medical failures and inaccuracies (Wilson et al., 2005) and decreases the patient mortality rate (West et al., 2006).

Table 1. Key characteristics of SL

\begin{tabular}{|c|c|c|c|}
\hline Perspectives & Key characteristic of SL & $\begin{array}{l}\text { The opposite } \\
\text { conditions }\end{array}$ & $\begin{array}{l}\text { Sample } \\
\text { references }\end{array}$ \\
\hline $\begin{array}{l}\text { Source } \\
\text { leadership } \\
\text { influence }\end{array}$ & $\begin{array}{l}\text { Horizontal, lateral leadership influence among peers } \\
\text { where team members take on the functions of } \\
\text { leadership traditionally handled by a designated or } \\
\text { elected leader }\end{array}$ & $\begin{array}{l}\text { Vertical leadership } \\
\text { influence from a } \\
\text { designated or elected } \\
\text { leader }\end{array}$ & $\begin{array}{l}\text { Pearce and } \\
\text { Conger } \\
(2003) \\
\text { Pearce and } \\
\text { Sims (2002) }\end{array}$ \\
\hline $\begin{array}{l}\text { Unit of analysis } \\
\text { (leadership at the } \\
\text { collective level) }\end{array}$ & $\begin{array}{l}\text { Views leadership as an emergent group - level } \\
\text { phenomenon }\end{array}$ & $\begin{array}{l}\text { Views leadership as an } \\
\text { individual action }\end{array}$ & $\begin{array}{l}\text { Carson et al. } \\
(2007) \\
\text { Chiu et al. } \\
(2016)\end{array}$ \\
\hline $\begin{array}{l}\text { Distribution of } \\
\text { leadership } \\
\text { influence }\end{array}$ & $\begin{array}{l}\text { Leadership influence or roles are dispersed widely } \\
\text { across team members }\end{array}$ & $\begin{array}{l}\text { Leadership influence or } \\
\text { roles are centralized } \\
\text { around a few individuals }\end{array}$ & $\begin{array}{l}\text { Carson et al. } \\
(2007) \\
\text { Drescher et al. } \\
(2014)\end{array}$ \\
\hline
\end{tabular}

Source: adapted from Zhu et al. 2018 p. 837.

The concepts "team", "organization", and "shared leadership" are very tightly connected with each other as seen from the research (Pearce et al., 2009; Kocolowski, 2010; Bolden, 2011). Most importantly, the good functioning of this relationship is expected to bring success, which is one of the researches aims to the studies (West et al., 2003). Shared leadership has come into prominence in the last years and identified by the scholars as a social process that calls for team leadership from the members likewise from the leader (Pearce et al., 2009). According to O'Toole et al., (2003) shared leadership is manifested in both traits and action, where the latter relies on collaboration. A search of google.co.uk on 20 March 2019 yielded 384.000 results for the phrase "distributed leadership" and books.google.co.uk returned 42.200 books referring to the topic. While, searching for "shared leadership" revealed 32.000 .000 results and books.google.co.uk yielded 498.000 books. According to the research of Bolden (2011) on the Scopus database, we get information regarding the publications on concepts related to distributed leadership (DL) and shared leadership (SL). Bolden reports to have accessed http://www.scopus.com on 26 January 2010, and his search is in the interval from 1980 until 2009. Interest on DL has been increased rapidly since the year 2000, while SL has had interest since the 1980s and the referring publications have been in a consistent trend beginning from the early 1990s (Note 1). Going further in the research of Bolden, he comes out with the result that SL is noticeably the preferred concept in nursing and medicine; DL is preferred concept in business, management and other social sciences areas. Concretely, $\% 39$ of SL articles was found to be published in journals relating healthcare (nursing and medicine) in proportion to no DL articles. Shared team leadership seems to have the potential to come to a very strong position in predicting the effectiveness of the organizations.

As shown in Table 1, Kocolowski, (2010) highlighted that SL in Healthcare studies received a good attention from scholars. From this study emerges that SL have permeated a broad range of fields from 1996 until 2008.

This study focuses on both vertical and shared leadership in their main constructs: transactional leadership, transformational leadership, and empowering leadership. The constructs have been extrapolated from Pearce \& Sims (2002). The transactional leadership behavioral type bases come from the expectancy theory of Vroom, 1964. According to the author, employees' personal goals can be attained by organizational rewards or work outcomes. Therefore, there exists a relationship between organizational reward or work outcomes and personal goals, and the crucial point is to what extent the employee's personal goals are fulfilled and how these rewards are satisfactory for the employee. 
If the employees are providing higher inputs, they are going to get higher rewards (Homans, 1961). Furthermore, employees are being more motivated in case they are getting rewards in a fair way (Adams, 1963). Therefore, exchange theory and equity theory (as by the respective authors) provide another basis to the transactional leadership behavioral type. Vroom (1964) developed the Expectancy Theory, which supports the aforementioned researchers.

Table 2. Studies of Shared Leadership

\begin{tabular}{|c|c|}
\hline Field of Study & Author \\
\hline \multirow{5}{*}{ Healthcare } & Jackson, 2000 \\
\hline & Konu \& Viitanen, 2008 \\
\hline & Merkens \& Spencer, 1998 \\
\hline & Spooner, Keenan, \& Card, 1997 \\
\hline & Steinert, Goebel, \& Rieger, 2006 \\
\hline \multirow{6}{*}{ Education } & Boardman, 2001 \\
\hline & Hall, 2001 \\
\hline & Meyers \& Johnson, 2008 \\
\hline & Prather, Hartshorn, \& McCreight, 1998 \\
\hline & Rice, 2006 \\
\hline & Wallace, 2001 \\
\hline New ventures & Ensley, Hmieleski, \& Pearce, 2006 \\
\hline Road maintenance teams & Hiller, Day, \& Vance, 2006 \\
\hline Equipment and engine manufacturing & Anderson, Anderson \& Mayo, 2008 \\
\hline Technology & Hsu \& Sharma, 2008 \\
\hline Local government & Berman, 1996 \\
\hline \multirow{2}{*}{ Sales teams } & Mehra, Smith, Dixon, \& Robertson, 2006 \\
\hline & Perry, Pearce, \& Sims, 1999 \\
\hline Police departments & Steinheider \& Wuestewald, 2008 \\
\hline Banks & Walker, Smither, \& Waldman, 2008 \\
\hline
\end{tabular}

Source: adapted from Kocolowski, 2010, p. 23.

This theory explains that the employees have personal goals for which they tend to work in organizations. These goals may be accomplished by the organizational rewards or the work outcomes. So, we can see that there exists a relationship between personal goals of the employee and the organizational rewards or the work outcomes, and the important point is to what extent the last two are satisfactory to the employee's personal goals.

The transformational leadership behavioral type bases on Weber's (1947) sociology of charisma (cf. Northouse, 2013), charismatic leadership theory (House, 1977), and transforming/transformational leadership (Bass, 1985; Burns, 1978). When explaining the relationship between transformational leadership and charisma, Northouse (2013) recalls the charisma definition from Weber (1947) who uses this word to describe the non-ordinary power and attributes of an individual. To be continued by House (1977) (cf. Northouse, 2013), it is also important the role followers play as affirming charisma in their leaders. In his theory of charismatic leadership, House (1977) suggested that charismatic leaders exhibit the following behaviors with the aim of attaining charismatic effects: impression management, articulation of ideological goals, definition of subordinate roles in terms of ideological values, role modeling, communication of high expectations and confidence in subordinates, and engagement in behavior planned to prompt proper follower motives (House, 1977; House et.al. 1993; House \& Shamir, 1993; Pearce \& Sims, 2002).

The studies have been oriented toward followers centered state rather than leaders 'needs in the mid-80s. Burns (1978) introduced the term "transforming leadership behavior" and clarified its difference from transactional leadership behavior. Bass (1985) extended Burns' research (1978) by inducing to the model the leader type who 
is not necessarily to be at highest values. Bass (1998) introduces in his model the behavior types as: charismatic leadership, inspirational motivation, intellectual stimulation, and individualized consideration.

The behaviors that represent the transformational leadership type are: providing vision, expressing idealism, using inspirational communication, having high performance expectations, and providing intellectual stimulation. These behaviors are included in this study as it can be seen in Appendix A.

The upcoming behavioral type is empowering leadership that underlines the importance of developing the self-management (self-leadership) skills by the followers. Manz \& Sims (2001) named this type of leadership as "SuperLeadership", in another meaning leading the others to lead themselves. Several studies have included self-management (self-leadership) study and emphasized its importance for the organizational goals. Huffman \& Hipp (2001) studied (mentioned) it in a 5-year national study in education sector. Lovelace et al. (2007) studied its mediating role in managing work stress. Pearce (2007) studied the importance of self-leadership (among several other factors) in the future of leadership development. Pearce et al. (2008) gave importance to this notion by introducing it in the role of the moderator in the enactment of executive corruption. Nielsen et al. (2009) studied the mediating effects towards job satisfaction in healthcare sector. Pearce et al. (2009) giving as example a wide range (500 companies) study in different companies once more investigated the role of self-leadership as a notion in team success. Shuffler et al. (2010) emphasized the role of self-leadership as a function of shared leadership studying virtual teams. The theoretical base of empowering leadership is behavioral self-management provided by Thorenson \& Mahoney (1974).

\subsection{Team Effectiveness}

Northouse (2013) described team effectiveness as the desired outcome of the teamwork. Assuming this, we conclude that team performance is an important step towards team effectiveness. Sparrowe et al. (2001) found that social networks as defined in terms of both positive and negative relations are interconnected to both individual and group performance. Pearce \& Sims (2002) studied vertical leadership versus shared leadership as predictors of effectiveness and found both of them significantly related to team effectiveness. Yet, shared leadership came to prominence as a more useful predictor of team effectiveness than vertical leadership. Hiller (2001) found shared leadership as a predictor of supervisor-rated team performance, and further suggested that shared leadership (especially in development and mentoring activities) may be an important antecedent of team effectiveness. Ozaralli (2003) measured perceived team effectiveness (besides empowerment) as transformational leadership affects it. Carson et al. (2007) found shared leadership to predict team performance as rated by clients and suggested that organizations looking from the viewpoint of customers or last users of a team's work should give importance to shared leadership as a critical factor that can improve team performance. Shared leadership predicted team performance by means of age diversity and team coordination as studied by Hoch et al. (2010). Drescher et al, (2014) studying how dynamics and dimensions of shared leadership are related to group performance and building trust results in enhancing of this performance. Their findings contributed positively to the literature. Hoch \& Kozlowski (2014) studied the impact of traditional leadership, structural support and shared leadership on team performance in virtual teams and found shared team leadership notably related to team performance regardless of the degree of virtuality. Similarly, Wang et al. (2014) found shared leadership strongly connected to team effectiveness, and shared leadership was found to have a stronger effect when the work is more complex.

To assess team effectiveness, it was integrated process and performance measures (Ancona \& Caldwell, 1992), and effectiveness measures (Manz \& Sims, 1987; Cox, 1994), such as: output effectiveness, quality effectiveness, planning effectiveness, interpersonal communication effectiveness, etc.

\subsection{Vertical, Shared Leadership and Team Effectiveness in Healthcare Organizations}

The shift from a single person to a "shared leadership" model calls for new concepts and methods in order to seize the nature and structure of leadership by teams (Yukl, 1998). The influence of shared leadership on team effectiveness has captured the attention of scholars (O'Toole et al., 2003; Pearce et al., 2009; Wang et al., 2014, Zhu et al., 2018).

Meindl et al. (2002) state that a social network approach could be helpful to provide a conceptual structure and scientific tools to support a shared leadership aspect. The concept of shared leadership takes into consideration the nature and distribution of influence to each of team members as they get leadership responsibilities (Meindl et al., 2002). This model finds support firstly from Pearce (1997) who used a behavioral leadership questionnaire asking team members for their perceptions of vertical and shared leadership. From this analysis came out the five behavioral influence strategies of shared leadership (aversive, directive, transactional, transformational, and empowerment). Secondly, the transactional and transformational theories of leadership have been successfully 
applied in a wide range of organizational contexture, which makes it furthermore effective as structurally. Lastly, the theory provides several leadership aspects which helps to conceptualize shared leadership from a various networks' perspective (Meindl et.al, 2002). The model developed by Meindl and colleagues consists of four degrees of shared leadership divided considering the density of leadership network (high or low), and the decentralization of the leadership network (high or low).

Regarding the healthcare organizations, many authors (i.e. Spooner et al., 1997; Merkens \& Spencer, 1998; Scott \& Caress, 2005; Steinert et al., 2006; Konu \& Viitanen, 2008) highlighted that shared leadership could be seen as a pathway to creating uniformity in decision-making and defining responsibilities as a means to improve outcomes. If it is clear, it is important to reflect also on the nature of teamwork in healthcare. As Weaver et al. (2014) highlighted, this type of teamwork is "often characterized by a dynamic team membership, participation on multiple teams and rapid team formation" (p. 361). The authors point outs that mainly in the healthcare sector and particularly in acute care settings, the team members have never worked together before, are formed under stressful circumstances and probably in the future they will no longer work together in the future. Those teams are so called "ad hoc" or "action" teams. In this teams, that are defined for a rapid formation, short lifespan and often without previous experience in working together, the leadership (shared or not) "would be to align the team goals, and the coordination of the activities regarding problem-solving" (ibidem). For example, Aufegger et al. (2019) in their systematic literature review on clinical team management provide arguments about the difficult to implement shared leadership for teams consisting of nurses and physicians due to the "hierarchy" that hinders effective collaboration across professional boundaries and that requires extensive preparatory work to overcome traditional professional demarcations. Consequently, innovative healthcare teams need leadership clarity, and their effectiveness might be influenced by different style of leadership, as hypothesized in the present research.

Based on the aforementioned literature, the aim of this research is to understand if both vertical and shared leadership can influence team effectiveness in healthcare organizations. Thus, the hypotheses investigated in this research are more formally stated as follows:

\section{$H_{1}$ : Vertical transactional leadership is a relevant predictor of team effectiveness in healthcare teams. \\ $\mathrm{H}_{2}$ : Vertical transformational leadership is a relevant predictor of team effectiveness in healthcare teams. \\ $H_{3}$ : Vertical empowering leadership is a relevant predictor of team effectiveness in healthcare teams. \\ $H_{4}$ : Shared transactional leadership is a relevant predictor of team effectiveness in healthcare teams. \\ $H_{5}$ : Shared transformational leadership is a relevant predictor of team effectiveness in healthcare teams. \\ $H_{6}$ : Shared empowering leadership is a relevant predictor of team effectiveness in healthcare teams.}

\section{Methodology}

\subsection{Sampling and Data Collection}

The sampling procedure was a random selection on the healthcare personnel to whom was delivered a structured questionnaire. The participants of the research working in private and state hospitals in Albania, in the cities of Tirana and Durres, which are the two biggest municipalities in the country. Tirana and Durres have the highest concentration of healthcare structures. The research intended to study 26 work teams in healthcare, but only 17 of these teams were possible to study and was administered by one of the authors during the master's studies. In total, there were 138 respondents.

Data were collected through a structured questionnaire by adopting the Likert scale. The questionnaire was formulated such that the participants responded to each item twice; firstly, for their own team leaders, and secondly for their team members by means of a general overview of their peers. From the first responses of each item, it has been observed the vertical leadership; from the second responses of each item, it has been observed the shared leadership. The technique of organizing the questionnaire allowed the participants to answer the same question alluding to both vertical leader behaviors (ex: My team leader encourages me to...) and to shared leader behavior (ex: My team members encourage me to...). In this way are provided "leader ratings" and "team's self-ratings". Additionally, the questionnaire is structured into five sections. The first one includes 5 questions related to biographical data. The second section is about Vertical/Shared Transactional Leadership, measured by questions 6-9. The third section refers to Vertical/Shared Transformational Leadership, measured by questions 10-16. The fourth section considers Vertical/Shared Empowering Leadership, measured by questions 17-22. Moreover, the last section deals with Team Effectiveness as measured by questions 24-33. Thus, to summarize; Vertical and Shared Leadership (17 questions: 6-22); Team Effectiveness (10 questions: 24-33). 


\subsection{Research Design}

A questionnaire originally designed by Pearce \& Sims (2002) was adapted and used for the aim of this study. The adaptation consists in a development of the leader's behavior questions. Pearce \& Sims (2002) firstly design their version of the questionnaire by using that Cox' one (1994) and of the one of Cox \& Sims (1996) and were concluded to be applied after being analyzed furthermore by Pearce et al. (2001). Shared leadership is most likely to be found in empowered teams (Pearce et al., 2001). Similarly, an empowering leader behavior strategy was included in the study. Starting from the analysis of Pearce et al. (2001) regarding the five leader behavior strategies (aversive, directive, transactional, transformational, and empowering), Pearce \& Sims (2002) integrated other items from other leadership researchers, when they judged it was convenient, in order to widen the range of behavior types studied. From Pearce's et.al. (2001) analysis, three of the strategies were used in this study: transactional, transformational, and empowering leader behavior strategy. Referring to Yukl's (1994) concept of encouraging self-development, Pearce \& Sims (2002) developed another leader behavior measure.

The technique of organizing the questionnaire allowed the participants to answer the same question alluding both to vertical leader behavior (ex: My team leaders encourages me to...) and to shared leader behavior (ex: My team members encourage me to...). The format of double responding has been used successfully in antecedent research with the aim to measure leadership from an external source versus an internal source (Manz \& Sims, 1987). The question: "How many of team's members execute leadership behaviors that contribute positively", is newly added to the questionnaire with the intent to obtain an approximate level of leadership capacity perceived by the team's own members. The measures used are the leader behavior and the team effectiveness. All measures were gathered with a 5-point scale with the following responses: 1 (definitely not true), 2 (not true), 3 (neither true nor untrue), 4 (true), and 5 (definitely true).

\subsection{Data Analysis}

Focusing our attention on the identification of three types of both Vertical and Shared Leadership Vertical/Shared Transactional Leadership, Vertical/Shared Transformational Leadership, Vertical/Shared Empowering Leadership - we analyze their effect on healthcare team effectiveness through the following process. As stated before, a questionnaire was designed and shared. By using IBM SPSS Statistics, the collected data were analyzed. Descriptive statistics to describe the basic characteristics of the data, including the correlation, were used. The Kaiser-Meyer-Olkin Measure of Sampling Adequacy and Bartlett's Test of Sphericity was conducted preliminary to next step of inferential statistics. An exploratory factor analysis was conducted on two types of leadership (vertical, shared) and three behavior strategies (transactional, transformational and empowering) for each type of leadership. According to Field (2011) and in order to reduce the set in a smaller number of items three steps of factor analysis for each type of leadership have been conducted. Thus, the analysis started with descriptive statistics, following by a correlation matrix. Then, Kaiser-Meyer-Olkin Measure of Sampling Adequacy and Barlett's Test of Sphericity were applied. Afterwards, the researchers analyzed the Communalities and the Total Variance Explained with the Principal Axis Method of Factor Extraction. Finally, in order to find the converged iterations, it was applied the Rotation Method (Varimax with Kaiser Normalization). The Rotated Factor Matrix can be reported as a conclusive phase of Factor Analysis where it was noticed a nicely distribution of the factors that seem to have the most variance of the problem. In the next paragraph are shown the results, which summarize better and in more pragmatically terms what have been already disclosed in this paragraph.

\section{Results}

As shown in Table 2, the respondents were 138. The age distribution of the respondents is the following $38.4 \%$ were between $25-29$ years old, $16.7 \%$ of them were between $30-34$ years old, $15.9 \%$ were between $35-39$ years old, $14.5 \%$ of them between $40-45$ years old, and lastly $14.5 \%$ of them were older than 45 years old.

According to the valid responds, $15.2 \%$ of the respondents reported to have been working in healthcare for a period $0-2$ years, other $29 \%$ of them were working for a period from $2-5$ years, $30.4 \%$ have been working for a period from 5-10 years, and 23.9\% were working for a period for more than 10 years in healthcare institution. 2 of the 138 participants didn't report on their length of service. 
Table 3. Description of respondents

\begin{tabular}{llrrrr}
\hline \multicolumn{1}{c}{ Department } & Frequency & Percent & Valid Percent & Cumulative Percent \\
\hline General Doctor & 30 & 21.7 & 22.1 & 22.1 \\
Radiology & 25 & 18.1 & 18.4 & 40.4 \\
Cardiology & 13 & 9.4 & 9.6 & 50.0 \\
Surgery & 7 & 5.1 & 5.1 & 55.1 \\
& Lab practitioner & 13 & 9.4 & 9.6 & 64.7 \\
Gynecology & 6 & 4.3 & 4.4 & 69.1 \\
& Ophthalmology & 9 & 6.5 & 6.6 & 75.7 \\
& Pediatrics & 10 & 7.2 & 7.4 & 83.1 \\
Anesthesiologists & 1 & .7 & .7 & 83.8 \\
& Pneumology & 1 & .7 & .7 & 84.6 \\
& Neurology & 1 & .7 & .7 & 85.3 \\
& Neurosurgery & 3 & 2.2 & 2.2 & 87.5 \\
& Orthopedics & 2 & 1.4 & 1.5 & 89.0 \\
& Urology & 1 & .7 & .7 & 89.7 \\
& Nursery & 6 & 4.3 & 4.4 & 94.1 \\
Dentistry & 6 & 4.3 & 4.4 & 98.5 \\
Intensive care & & 1.4 & 1.5 & 100.0 \\
\hline & Total & 136 & 98.6 & 100.0 & \\
\hline
\end{tabular}

In the following Tab. 4 and 5 the principal axis factor analysis with varimax rotation was conducted to assess the underlying structure for the 17 questions that relate to the Vertical Leadership. From the correlation matrix 4 questions were removed from the analysis since 2 of them $(3 \& 4)$ showed very small intercorrelation with other variables and 2 other questions $(9 \& 17)$ showed very strong correlation (almost perfect) with other variables. Question 16 and question 17 were very strongly correlated and this could raise the problem of multicollinearity. After the rotation, the first factor accounted for $17.7 \%$ of the variance with an eigenvalue of 2.30 ; the second factor accounted for $17 \%$ of the variance with an eigenvalue of 2.23 ; and the third accounted for $13 \%$ of the variance with an eigenvalue of 1.70 .

Table 4. Exploratory factor analysis of vertical leadership

\begin{tabular}{|c|c|c|c|}
\hline \multirow[t]{2}{*}{ Here we remove factors that are smaller than 0.4. } & \multicolumn{3}{|c|}{ Factor } \\
\hline & 1 & 2 & 3 \\
\hline Leader provides clear vision of what the team capacity is & .73 & & \\
\hline Leader seeks a broad range of perspectives when solving problems & 60 & & \\
\hline Leader is driven by high purpose or ideals & .57 & & \\
\hline Leader encourages me to go above and beyond of what is normally expected & .53 & .49 & \\
\hline Leader encourages me to develop myself & .48 & & .46 \\
\hline \multicolumn{4}{|l|}{ Leader expects me to perform at my highest level } \\
\hline Leader encourages me to work together with other team members & & .85 & \\
\hline Leader gives me positive feedback when I perform well & & .63 & \\
\hline Leader emphasizes the value of questioning team members & & .50 & \\
\hline Leader encourages me to search for solutions to my problems w/o supervision & & & .74 \\
\hline Leader encourages me to treat myself to something I enjoy when I do a task especially well & & & .59 \\
\hline Leader advises me to look for opportunities in the problems I face & & & .41 \\
\hline \multicolumn{4}{|l|}{ Leader recommends that I am compensated well if I perform well } \\
\hline \multicolumn{4}{|l|}{ Extraction Method: Principal Axis Factoring. } \\
\hline Rotation Method: Varimax with Kaiser Normalization. & & & \\
\hline a. Rotation converged in 7 iterations. & & & \\
\hline
\end{tabular}

Factor 1 can be a variable constructed by the questions:

i. Leader provides clear vision of what the team capacity is; 
ii. Leader seeks a broad range of perspectives when solving problems;

iii. Leader is driven by high purpose or ideals, iv) Leader encourages me to go above and beyond of what is normally expected;

iv.Leader encourages me to develop myself (as can be seen from the table)

Factor 2 can be a variable constructed by the questions: i) Leader expects me to perform at my highest level, ii) Leader encourages me to work together with other team members, iii) Leader gives me positive feedback when I perform well, iv) Leader emphasizes the value of questioning team members, v) Leader encourages me to search for solutions to my problems w/o supervision.

Factor 3 can be a variable constructed by the questions: i) Leader encourages me to treat myself to something I enjoy when I do a task especially well, ii) Leader advises me to look for opportunities in the problems I face, iii) Leader recommends that I am compensated well if I perform well.

From the exploratory Factor Analysis related to the vertical leadership, we notice that we have a more nicely distribution of the factors that seem to have the most variance of the problem. We can report this as a conclusive Factor Analysis of the vertical leadership. In addition, the determinant at the Factor Analysis 1 and FA2 was zero, whereas the determinant found for FA3 is equal to .005 . Since the determinant is larger than zero, then the Factor Analysis can be conducted with higher reliability.

We conduct also the exploratory Factor Analysis for the Shared Leadership (Tab. 5), by using the similar steps with the ones in the Vertical Leadership. Out of 17 questions, questions 3, 4, 9, and 17 were removed. The correlation matrix has determinant of 0.006 , and since it is larger than 0 , the factor analysis provides a reliable result.

Principal axis factor analysis with varimax rotation was conducted to assess the underlying structure for the 17 questions that relate to the Shared Leadership. From the correlation matrix four questions were removed from the analysis since two of them (question $3 \&$ questions 4) showed very small intercorrelation with other variables and two other questions (question 9 and question 17) showed very strong correlation (almost perfect) with other variables. Question 16 and question 17 were very strongly correlated and this could raise the problem of multicollinearity. After the rotation, the first factor accounted for $22.2 \%$ of the variance with an eigenvalue of 2.89 ; the second factor accounted for $17.8 \%$ of the variance with an eigenvalue of 2.3 ; and the third accounted for $8 \%$ of the variance with an eigenvalue of 1.05 .

Table 5. Exploratory Factor Analysis of Shared leadership

\begin{tabular}{|c|c|c|c|}
\hline \multirow{2}{*}{ Here in this table, we simplify by removing the items with a weight smaller than 0.4} & \multicolumn{3}{|c|}{ Factor } \\
\hline & 1 & 2 & 3 \\
\hline Member provides clear vision of what the team capacity is & .721 & & \\
\hline Member is driven by high purpose or ideals & .696 & & \\
\hline Member encourages me to go above and beyond of what is normally expected & .594 & & \\
\hline Member gives me positive feedback when I perform well & .552 & & .415 \\
\hline Member encourages me to work together with other team members & .550 & & \\
\hline Member encourages me to treat myself to something I enjoy when I do a task especially well & .491 & & .407 \\
\hline \multicolumn{4}{|l|}{ Member expects me to perform at my highest level } \\
\hline Member advises me to look for opportunities contained in the problems I face & & .731 & \\
\hline Member encourages me to develop myself & .407 & .602 & \\
\hline Member encourages me to search for solutions to my problems without supervision & & .585 & \\
\hline Member emphasizes the value of questioning team members & & .540 & \\
\hline Member seeks a broad range of perspectives when solving problems & .475 & .519 & \\
\hline Member recommends that I am compensated well if I perform well & & & .711 \\
\hline \multicolumn{4}{|l|}{ Extraction Method: Principal Axis Factoring. } \\
\hline Rotation Method: Varimax with Kaiser Normalization. & & & \\
\hline a. Rotation converged in 5 iterations. & & & \\
\hline
\end{tabular}

Factor 1 can be a variable constructed by the questions: i) Member provides clear vision of what the team capacity is, ii) Member is driven by high purpose or ideals, iii) Member encourages me to go above and beyond of what is normally expected, iv) Member gives me positive feedback when I perform well, v) Member encourages me to work together with other team members (as can be seen from the table) 
Factor 2 can be a variable constructed by the questions: i) Member advises me to look for opportunities contained in the problems I face, ii) Member encourages me to develop myself, iii) Member encourages me to search for solutions to my problems without supervision, iv) Member emphasizes the vallue of questioning team members, v) Member seeks a broad range of perspectives when solving problems.

Factor 3 can be a variable constructed by the questions: i) Member gives me positive feedback when I perform well, ii) Member encourages me to treat myself to something I enjoy when I do a task especially well, iii) Member recommends that I am compensated well if I perform well.

In the next Tab. 6 the means (M), standard deviations (SD) and intercorrelations among variables are provided.

Table 6. The means and correlations among the variables

\begin{tabular}{lllllllll}
\hline Variable & $\mathrm{M}$ & $\mathrm{SD}$ & 1 & 2 & 3 & 4 & 5 & 6 \\
\hline 1.Vertical transactional & 3.41 & 0.68 & -- & & & & & \\
2.Vertical transformational & 3.85 & 0.69 & $.368^{* *}$ & -- & & & & \\
3.Vertical empowering & 3.76 & 0.73 & $.357^{* *}$ & $.778^{* *}$ & -- & & & \\
4.Shared transactional & 3.42 & 0.70 & $.589^{* *}$ & $.356^{* *}$ & $.299^{* *}$ & -- & & \\
5.Shared transformational & 3.80 & 0.67 & $.266^{* *}$ & $.660^{* *}$ & $.457^{* *}$ & $.488^{* *}$ & -- & \\
6.Shared empowering & 3.70 & 0.75 & $.310^{* *}$ & $.462^{* *}$ & $.528^{* *}$ & $.517^{* *}$ & $.757^{* *}$ & -- \\
\hline
\end{tabular}

We checked for the effect of the (i) vertical transactional leadership, (ii) vertical management by exception leadership (iii) vertical transformational leadership and (iv) vertical empowering leadership on the team effectiveness.

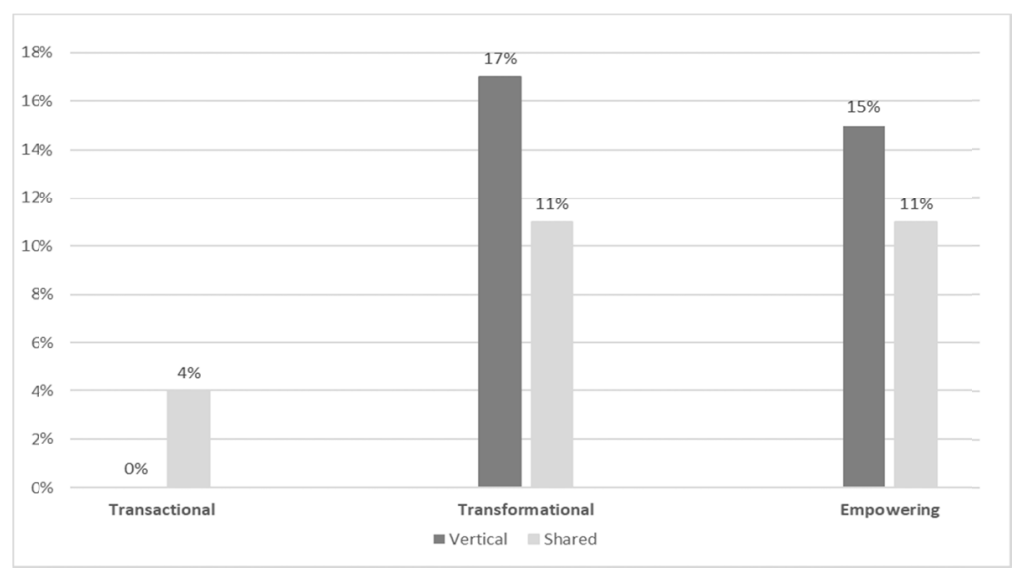

Figure 1. The variance of TE

Vertical management by exception is a construct that is part of the vertical transactional leadership variable and we analyzed if separately since it was not strongly correlated with the other constructs that make up the vertical transactional leadership. The vertical empowering leadership (VEL) and the vertical transformational leadership (VTfL) significantly predict the team effectiveness (TE). There is no significant dependence of the team effectiveness on vertical transactional leadership (VTL) and on vertical management by exception. VTfL predicts $17 \%$ of the variance of the TE, and VEL predicts $15 \%$ of the variance of the TE.

In contrast with the analysis of the TE as a function of the vertical leadership, the TE is significantly dependent on the three major shared leadership constructs. Shared transformational leadership (ShTfL) predicts $11 \%$ of the variance, shared empowering leadership (ShEL) predicts $11 \%$ and shared transactional leadership (ShTL) predicts $4 \%$ of the variance of the TE. The rating of the team effectiveness has a maximum of 4.01 and seem to have the least variance with a standard deviation of $\mathrm{SD}=0.59$.

The variance of the team effectiveness that is predicted by the vertical/shared transactional leadership $(0 \%$ / $4 \%)$, the vertical/shared transformational leadership (17\% / 11\%) and vertical/shared empowering leadership (15\% / 11\%) (Figure 1). 


\section{Discussion}

"Team" concept structures have taken the throne of hierarchical structures in the organizations, and consequently shared leadership is coming forward in the observations of the researchers (Avolio et al., 2009). The aim to reach the common goals that have been established by the members of a group or organization can be obtained more easily through interactive and dynamic influence process among the members of the team. This process is the one to be referred as shared leadership (Pearce \& Conger, 2003). With this increasing importance of studying and reflecting on team, related concepts (teamwork, team leadership); consequently, team effectiveness comes to prominence.

Two types of leadership variables were defined and measured: vertical leadership and shared leadership. Each of these variables was composed of three types of behaviors: the transactional leadership, the transformational leadership and the empowering leadership. The most important result of this study is that all three types (transactional, transformational and empowering) of shared leadership were found to be significant predictors of team effectiveness, and for this reason $\mathrm{H}_{4}, \mathrm{H}_{5}$, and $\mathrm{H}_{6}$ are supported. Regarding the vertical leadership, only two types (transformational and empowering) were found to be significant predictors of the team effectiveness (fig. 1) and for this reason $\mathrm{H}_{2}$ and $\mathrm{H}_{3}$ are supported while $\mathrm{H}_{1}$ is not supported.

The variance that is independently predicted by the two types of vertical leadership, respectively $17 \%$ and $15 \%$ of the variance of the team effectiveness and is predicted by the transformational and empowering vertical leadership is larger than the variance that is independently predicted by any of the three types of the shared leadership. The transactional shared leadership predicts $4 \%$ of the variance of the team effectiveness, the transformational shared leadership predicts $11 \%$ and the empowering shared leadership predicts $11 \%$ of the variance of the team effectiveness.

We separated the respondents in two different sets: one that was not supportive and one that was supportive. The team that was supportive was defined as one with two or more members that have leadership behavior. We observed that teams that were more supportive did not have significantly larger team effectiveness but had a significantly larger (i) shared transactional, (ii) shared transformational and (iii) shared empowering leadership.

The main practical implications of this study are referred to the training and team design. Differently from the seminal study of Pearce and Sims, actually the shared leadership have captured attention from scholars and more studies that this consideration of the authors is now outdated.

\section{Conclusion, Limitations and Future Research}

The findings of this paper contribute to growing the body of knowledge in leadership. Vertical and shared leadership and the respectively behaviors strategy (transactional, transformational and empowering) has been defined and measured in order to test their predictive ability of the team effectiveness, defined in 6 hypotheses. Data analysis showed that shared leadership (in all behaviors strategy) is a relevant predictor of team effectiveness in healthcare teams $\left(\mathrm{H}_{4}, \mathrm{H}_{5}, \mathrm{H}_{6}\right.$ are supported). This result is in line with the previous literature (Avoilo et al., 1996; Pearce \& Sims, 2002; Hiller et al., 2006; Zaccaro et al. 2009; Wang et al., 2014; Wu et al. 2018).

About the Vertical Leadership, the results of our study also shown that the vertical leadership is a relevant predictor of team effectiveness for the transformational and empowering behavior $\left(\mathrm{H}_{2}\right.$ and $\left.\mathrm{H}_{3}\right)$ while is not a predictor for the transactional behavior strategy ( $\mathrm{H}_{1}$ is non supported). The results (related to $\mathrm{H}_{1}$ and $\mathrm{H}_{2}$ ) are in line with the previous result of Pearce \& Sims (2002) and Avoilo et al. (1996; 2009), except for the transactional vertical leadership.

Differently from the work of Pearche \& Sims (2002) that was realized in a major country (U.S.A.) and in a manufacturing sector, this study has been realized in a developing country and in the healthcare sector. Also considering the results of this study ( $\mathrm{H}_{1}$ not supported and all the others supported), these two aspects make the paper unique and original.

These results have both theoretical and practical implication. The firsts are related to the leadership theory and to the strategic management, having shared and vertical leadership a relevant role in the knowledge management and how this impact on the strategic management aspects.

From a practical point of view, considering the important size of the healthcare sector in the actual economy and that, as shown, the vertical (except transactional behavior strategy) and shared leadership are a relevant predictors of team effectiveness in the healthcare, it is possible conclude with two main considerations. Firstly, by using a vertical (except transactional behavior strategy) and shared leadership as predictors of team effectiveness in healthcare, the team effectiveness can enhance the human well-being and from this side each 
(profit or non-profit) organization can create more value for itself (e.g. brand/image reputation) and for the customers (patient and their parents, friends, etc...). So, leveraging on the cultural aspect of vertical and shared leadership as predictor of team effectiveness, more value can be created. Secondly, from this point, the management of these organizations can concentrate more attention on these strategic aspects by allocating more investments for value creation through the awareness of shared and vertical leadership and their predictive ability of team effectiveness.

The limitation of this study is the small sample. Nevertheless, the number of teams involved in this study is representative of the capital of Albania (Tirana), and since Albania is a country not extremely populous (both in terms of inhabitants and in terms of hospital structures and teams) this suggests that this study can be confirmed in future research and results can be generalize.

Future research can be address about the generalization of these results, or that vertical (except transactional behavior strategy) and shared leadership are a predictive of team effectiveness in healthcare teams in the developing countries. So, it can be realized a first step useful to confirm this exploratory study in Albania and, as second step, realize the same study in other developing countries. The third step can be a cross comparative study. Another direction can be an in deep investigation to better understand both the theoretical and practical implications about the non-predictivity of team effectiveness of vertical transactional behavior strategy considering that, from literature, this is an original result.

\section{References}

Adams, J. S. (1963). Wage inequities, productivity and work quality. Industrial Relations, 3, 9-16.

Ancona, D. G., \& Caldwell, D. F. (1992). Bridging the boundary: External process and performance in organizational teams. Administrative Science Quarterly, 37, 527-548.

Anderson, M. C., Anderson, D. L., \& Mayo, W. D. (2008). Team coaching helps a leadership team drive cultural change at Caterpillar. Global Business and Organizational Excellence, 27(4), 40-50.

Aufegger, L., Shariq, O., Bicknell, C., Ashrafian, H., Darzi, A. (2019). Can shared leadership enhance clinical team management? A systematic review Leadership in Health Services, 32(2), 309-335. https://doi.org/10.1108/LHS-06-2018-0033

Avolio, B. J., Jung, D. I., Murry, W., \& Sivasubramaniam, N. (1996). Building highly developed teams: Focusing on shared leadership processes, efficacy, trust and performance. Advances in Interdisciplinary Studies on Work Teams, 3, 173-209.

Avolio, B. J., Walumbwa, F. O., \& Weber, T. J. (2009). Leadership: Current Theories, Research, and Future $\begin{array}{llllll}\text { Directions. Annual } & \text { Review }\end{array}$ https://doi.org/10.1146/annurev.psych.60.110707.163621

Bass, B. M. (1985). Leadership and performance beyond expectations. New York: Free Press.

Bass, B. M. (1990). Bass and Stogdill's handbook of leadership: Theory, research and managerial applications (3rd ed.). New York: Free Press.

Bass, B. M. (1998). Transformational leadership: Industrial, military, and educational impact. Hillsdale: NJ Erlbaum.

Bennett, N., Harvey, J. A., Wise, C., \& Woods, P. A. (2003). Distributed Leadership: A Desk Study', www.ncsl.org.uk/literature reviews.

Berman, E. M. (1996). Local government and community-based strategies: Evidence from a national survey of a social problem. American Review of Public Administration, 26(1), 71-91.

Block, L. (2003). The leadership-culture connection: An exploratory investigation. Leadership \& Organization Development Journal, 24(6), 318-334. https://doi.org/10.1108/01437730310494293

Boardman, M. (2001). The value of shared leadership: Tasmanian Teachers' and Leaders' Differing Views. International Studies in Educational Administration, 29(3), 2-9.

Bolden, R. (2011). Distributed leadership in organizations: A review of theory and research. International Journal of Management Reviews, 13(3), 251-269. https://doi.org/10.1111/j.1468-2370.2011.00306.x

Brown, A. (1992). Organizational culture: the key to effective leadership and organizational development. Leadership \& Organization Development Journal, 13(2), 3-6. https://doi.org/10.1108/01437739210009545

Burns, J. M. (1978). Leadership. New York: Harper \& Row. 
Canadian Health Leadership Network (CHLNet), (2014). 2014 Annual Report. Report retrieved from http://chlnet.ca/wp-content/uploads/CHLNet-Annual-Report-2014.pdf

Carson, J. B., Tesluk, P. E., \& Marrone, J. A. (2007). Shared leadership in teams: An investigation of antecedent conditions and performance. Academy of Management Journal, 50(5), 1217-1234. https://doi.org/10.2307/20159921

Chemers, M. M. (1997). An Integrative Theory of Leadership. Mahwah, NJ: Erlbaum.

Chemers, M. M. (2000). Leadership research and theory: A functional integration. Group Dynamics: Theory, Research, and Practice, 4(1), 27-43. http://dx.doi.org/10.1037/1089-2699.4.1.27

Chemers, M. M. (2003). Leader Effectiveness: Functional, Constructivist and Empirical Perspectives. In van Knippenberg \& Hogg, M. A. (eds). Leadership and Power. Identity Processes in Groups and Organizations, Sage Publications, Thousand Oaks, London, U.K., pp. 5-17, ISBN 0761947035 (pbk).

Conger, J. A. (1993). Training leaders for the twenty-first century. Human Resource Management Review, 3 , 203-218.

Cox, J. F. (1994). The effects of superleadership training on leader behavior, subordinate self-leadership behavior and subordinate citizenship. Unpublished doctoral dissertation, University of Maryland, College Park.

Cox, J. F., \& Sims, H. P. (1996). Leadership and team citizenship behavior: A model and measures. Advances in Interdisciplinary Studies of Work Teams, 3, 1-41.

Dougherty, D. \& Conway, P. H. (2008). The “3T's" Road Map to Transform US Health Care. The "How" of High-Quality Care. Journal American Medical Association, 299(19), 2319-2321. http://dx.doi.org/10.1001/jama.299.19.2319

Drescher, M. A., Korsgaard, M. A., Welpe, I. M., Picot, A., \& Wigand, R. T. (2014). The dynamics of shared leadership: Building trust and enhancing performance. Journal of Applied Psychology, 99(5), 771-783. http://dx.doi.org/10.1037/a0036474

Ensley, M. D., Hmieleski, K. M., \& Pearce, C. L. (2006). The importance of vertical and shared leadership within new venture top management teams: Implications for the performance of startups. The Leadership Quarterly, 17(3), 217-231.

Field, A. (2011). Discovering Statistics using SPSS, 3rd Edition, London: Sage.

Gilca, V., Boulianne, N., Dubè, E., Sauvageau, C., \& Ouakki, M. (2009). Attitudes of nurses toward current and proposed vaccines for public programs: A questionnaire survey. International Journal of Nursing Studies, 46 (9), 1219-1235. http://dx.doi.org/10.1016/j.ijnurstu.2009.02.013

Hall, V. (2001). Management teams in education: An unequal music. School Leadership \& Management, 21(3), 327-341.

Hambrick, D. C., Finkelstein, S., \& Mooney, A. C. (2005). Executive job demands: new insights for explaining strategic decisions and leader behavior. The Academy of Management Review, 30(3), 472-491. https://doi.org/10.5465/amr.2005.17293355

Harris, A. (2004). Distributed Leadership and School Improvement. Educational Management Administration \& Leadership, 32(1), 11-24. http://dx.doi.org/10.1177/1741143204039297

Hiller, N. J. (2001). Understanding and measuring shared leadership in work teams (Doctoral dissertation, Pennsylvania State University).

Hiller, N. J., Day, D. V., \& Vance, R. J. (2006). Collective enactment of leadership roles and team effectiveness: A field study. The Leadership Quarterly, 17(4), 387-397.

Hoch, J. E., Pearce, C. L., \& Welzel, L. (2010). Is the Most Effective Team Leadership Shared? TThe impact of shared leadership, age diversity, and coordination on team performance. Journal of Personnel Psychology, 9(3), 105-116. http://dx.doi.org/10.1027/1866-5888/a000020

Hoch, J. E., \& Kozlowski, S. W. J. (2014). Leading virtual teams: Hierarchical leadership, structural supports, and shared team leadership. Journal of Applied Psychology, 99(3), 390-403. http://dx.doi.org/390-403.10.1037/a0030264

Hogg, M. A., Martin, R., Epitropaki, O., Mankad, A., Svensson, A., \& Weeden, K. (2005). Effective leadership in salient groups: revisiting leader-member exchange theory from the perspective of the social identity 
theory of leadership. Personality and Social Psychology Bulletin, 31(7), 991-1004. http://dx.doi.org/10.1177/0146167204273098

Homans, G. C. (1961). Social behavior: Its elementary forms. New York: Harcourt, Brace.

House, R. J. (1977). A 1976 theory of charismatic leadership. In J. G. Hunt \& L. L. Larson (Eds.), Leadership: The cutting edge (pp. 189-207). Carbondale: Southern Illinois University Press.

House, R. J., \& Shamir, B. (1993). Toward the integration of transformational, charismatic and visionary theories of leadership. In M. Chemmers \& R. Ayman (Eds.), Leadership: Perspectives and research directions (pp. 81-107). New York: Academic Press.

House, R. J., Howell, J. M., Shamir, B., Smith, B., \& Spangler, W. D. (1993). Charismatic leadership: A 1993 theory and five empirical tests. Unpublished manuscript, University of Pennsylvania.

Hsu, P. S., \& Sharma, P. (2008). A case study of enabling factors in the technology integration change process. Educational Technology \& Society, 11(4), 213-228.

Huffman, J. B., \& Hipp, K. A. (2001). Creating communities of learners: The interaction of shared leadership, shared vision, and supportive conditions. International Journal of Educational Reform, 10(3), 272-281. https://doi.org/10.1177/105678790101000305

Inghelbrecht, E., Bilsen, J., Mortier, F., \& Deliens, L. (2009). Attitudes of nurses towards euthanasia and towards their role in euthanasia: A nationwide study in Flanders, Belgium. International Journal of Nursing Studies, 46(9), 1209-1218. https://doi.org/1209-1218. 10.1016/j.ijnurstu.2009.02.009

Jackson, S. (2000). A qualitative evaluation of shared leadership barriers, drivers and recommendations. Journal of Management in Medicine, 14(3/4), 166-178. https://doi.org/10.1108/02689230010359174

Jones, R., Kriflik, G. (2006). Subordinate expectations of leadership within a cleaned-up bureaucracy: A grounded theory study. Journal of Organizational Change Management, 19(2), 154-172. https://doi.org/10.1108/09534810610648889

Kocolowsvki, M. D. (2010). Shared leadership: Is it time for a change? Emerging Leadership Journeys, 3(1), 22-32.

Konu, A., \& Viitanen, E. (2008). Shared leadership in Finnish social and health care. Leadership in Health Services, 21(1), 28-40. https://doi.org/10.1108/17511870810845888

Kotter J. P. (1990). A force for Change: How Leadership Differs from Management. New York, Free Press.

Kotter J. P. (1990a). What leaders really do. Harvard Business Review, 68(3), 103-111.

Krishnan, V. R. (2003). Power and moral leadership: Role of self-other agreement. Leadership \& Organization Development Journal, 24(6), 345-351. http://dx.doi.org/10.1108/01437730310494310

Lovelace, K. J., Manz, C. C., \& Alves, J. C. (2007). Work stress and leadership development: The role of self-leadership, shared leadership, physical fitness and flow in managing demands and increasing job control. Human Resource Management Review, 17(4), 374-387. http://dx.doi.org/10.1016/j.hrmr.2007.08.001

Manz, C. C., \& Sims, H. P., Jr. (1987). Leading workers to lead themselves: The external leadership of self-managing work teams. Administrative Science Quarterly, 32(1), 106-129. http://dx.doi.org/10.2307/2392745

Manz, C. C., \& Sims, H. P., Jr. (2001). The new SuperLeadership: Leading others to lead themselves. San Francisco, U.S.A., Berrett-Koehler.

Mehra, A., Smith, B. R., Dixon, A. L., \& Robertson, B. (2006). Distributed leadership in teams: The network of leadership perceptions and team performance. The Leadership Quarterly, 17(3), 232-245.

Meindl, J. R., Mayo, M., \& Pastor, J. C. (2002). Shared leadership in work teams: A social network approach. Instituto de Empresa (IE) Working Paper.

Merkens, B. J., \& Spencer, J. S. (1998). A successful and necessary evolution to shared leadership: A hospital's story. International Journal of Health Care Quality Assurance, 11(1), I-IV.

Meyers, R. A., \& Johnson, J. R. (2008). Facilitating the design of a campus leadership team. Communication Education, 57(4), 472-481. 
Nicolaides, V. C., LaPort, K. A., Chen, T. R., Tomassetti, A. J., Weis, E. J., Zaccaro, S. J., \& Cortina, J. M. (2014). The shared leadership of teams: A meta - analysis of proximal, distal, and moderating relationships. The Leadership Quarterly, 25(5), 923-942. http://doi.org/10.1016/j.leaqua.2014.06.006

Nielsen, K., Yarker, J., Randall, R., \& Munir, F. (2009). The mediating effects of team and self-efficacy on the relationship between transformational leadership, and job satisfaction and psychological well-being in healthcare professionals: A cross-sectional questionnaire survey. International Journal of Nursing Studies, 46(9), http://doi.org/1236-1244. 10.1016/j.ijnurstu.2009.03.001

Northouse, P. G. (2013). Leadership: Theory and Practice, (6th ed). Sage Publications, Thousand Oaks, CA.

O'Toole, J., Galbraith, J., \& Lawler III, E. E. (2003). The promise and pitfalls of shared leadership: When two (or more) heads are better than one. In C. L. Pearce, \& J. A. Conger (Eds.), Shared leadership: Reframing the hows and whys of leadership (pp. 250-267), Thousand Oaks, CA: Sage Publications.

Ozaralli, N. (2003). Effects of transformational leadership on empowerment and team effectiveness. Leadership \& Organization Development Journal, 24(6), 335-344. https://doi.org/10.1108/01437730310494301

Parry, K. W. (1998). Grounded theory and social process: A new direction for leadership research. The Leadership Quarterly, 9(1), 85-105. https://doi.org/10.1016/S1048-9843(98)90043-1

Parry, K. W. (1999). Enhancing adaptability: leadership strategies to accommodate change in local government settings. Journal of Organizational Change Management, 12(2), 134-156. https://doi.org/10.1108/09534819910263677

Pearce, C. L. (1997). The determinants of change management team (CMT) effectiveness: A longitudinal investigation. Unpublished doctoral dissertation, University of Maryland, College Park.

Pearce, C. L. (2007). The future of leadership development: The importance of identity, multi-level approaches, self-leadership, physical fitness, shared leadership, networking, creativity, emotions, spirituality and on-boarding processes. Human Resource Management Review, 17(4), 355-359. https://doi.org/10.1016/j.hrmr.2007.08.006

Pearce, C. L., Perry, M. L., \& Sims, H. P., Jr. (2001). Shared leadership: Relationship management to improve NPO effectiveness. In T. D. Connors (Ed.), The nonprofit handbook: Management (pp. 624-641), New York; Wiley.

Pearce, C. L., \& Sims, H. P., Jr. (2002). Vertical versus shared leadership as predictors of the effectiveness of change management teams: An examination of aversive, directive, transactional, transformational, and empowering leader behaviors. Group Dynamics: Theory, Research, and Practice, 6(2), 172-197. http://dx.doi.org/10.1037/1089-2699.6.2.172

Pearce, C. L., \& Conger, J. A. (Eds.). (2003). Shared leadership: Reframing the how's and why's of leadership. Thousand Oaks, CA: Sage Publications.

Pearce, C. L., Manz, C. C., \& Sims, H. P. Jr. (2008). The roles of vertical and shared leadership in the enactment of executive corruption: Implications for research and practice. The Leadership Quarterly, 19(3), 353-359. http://dx.doi.org/10.1016/j.leaqua.2008.03.007

Pearce, C. L., Manz, C. C., \& Sims, H. P. Jr. (2009). Where do we go from here? Is shared leadership the key to team success? Organizational Dynamics, 38(3), 234-238. http://dx.doi.org/10.1016/j.orgdyn.2009.04.008

Perry, M. L., Pearce, C. L., \& Sims, H. P. (1999). Empowered selling teams: How shared leadership can contribute to selling team outcomes. Journal of Personal Selling \& Sales Management, 19(3), 35-51.

Petrie, N. (2014). Vertical leadership development (part 1). Developing leaders for a complex world. Center for Creative Leadership.

Podolny, J., M., Khurana, R., \& Hill-Popper, M. (2005). Revisiting the meaning of leadership. Research in Organizational Behavior, 26, 1-36. https://doi.org/10.1016/S0191-3085(04)26001-4

Prather, J., Hartshorn, R., \& McCreight, D. (1988). A team leadership development program: The Elementary Science Education Institute (ESEI). Education, 108(4), 454-462.

Pucic, J. (2011). Ethical leadership in the employment relationship: evidence from three Canadian surveys. Ph.D Thesis, Centre for Industrial Relations and Human Resources, Canada: University of Toronto.

Pucic, J. (2015). Do as I Say (and Do): Ethical Leadership Through the Eyes of Lower Ranks. Journal of Business Ethics, 129(3), 655-671. http://dx.doi.org/10.1007/s10551-014-2190-z 
Rice, N. (2006). Opportunities lost, possibilities found: Shared leadership and inclusion in an urban high school. Journal of Disability Policy Studies, 17(2), 88-100.

Rost, J. C. (1991). Leadership for the Twenty-first Century. New York: Greenwood.

Scott, L. \& Caress, A. (2005). Shared governance and shared leadership: meeting the challenges of implementation. Journal Nursing Management, $13(1)$ 4-12. https://doi.org/10.1111/j.1365-2834.2004.00455.x

Shuffler, M. L., Wiese, C. W., Salas, E., \& Burke, C. Sh. (2010). Leading one another across time and space: Exploring shared leadership functions in virtual teams. Revista de Psicologia del Trabajo y de las Organizaciones, 26(1), 3-17.

Sparks, K., Faragher, B., \& Cooper, C. L. (2010). Well - being and occupational health in the 21st century workplace. Journal of Occupational and Organizational Psychology, 74(4), 489-509. https://doi.org/10.1348/096317901167497

Sparrowe, R. T., Liden, R. C., \& Kraimer, M. L. (2001). Social networks and the performance of individuals and groups. Academy of Management Journal, 44(2), 316-325. https://doi.org/10.2307/3069458

Spooner, S. H., Keenan, R., \& Card, M. (1997). Determining if shared leadership is being practiced: Evaluation methodology. Nursing Administration Quarterly, 22(1), 47-56.

Steinert, T., Goebel, R., \& Rieger, W. (2006). A nurse-physician co-leadership model in psychiatric hospitals: Results of a survey among leading staff members in three sites. International Journal of Mental Health Nursing, 15(4), 251-258. https://doi.org/10.1111/j.1447-0349.2006.00431.x

Steinheider, B., \& Wuestewald, T. (2008). From the bottom-up: Sharing leadership in a police agency. Police Practice \& Research, 9(2), 145-163.

Stogdill, R. M. (1974). Handbook of leadership. New York: Free Press.

Thorenson, E. E., \& Mahoney, M. J. (1974). Behavioral self-control. New York: Holt, Rinehart \& Winston.

Van Langenhove L., Zwartjes M., \& Papanagnou G. (2016). Conceptualising Regional Leadership: The Positioning Theory Angle. In: Kingah S., \& Quiliconi C. (eds) Global and Regional Leadership of BRICS Countries (pp. 13-27). United Nations University Series on Regionalism, vol 11. Springer, Cham. https://doi.org/10.1007/978-3-319-22972-0_2

Vroom, V. H. (1964). Work and motivation. New York: Wiley.

Walker, A. G., Smither, J. W., \& Waldman, D. (2008). A longitudinal examination of concomitant changes in team leadership and customer satisfaction. Personnel Psychology, 61(3), 547-577.

Wallace, M. (2001). Sharing leadership of schools through teamwork. Educational Management \& Administration, 29(2), 153-167.

Wang, D., Waldman, D. A., \& Zhang Z. (2014). A meta-analysis of shared leadership and team effectiveness. Journal of Applied Psychology, 99(2), 181-198. https://doi.org/10.1037/a0034531

Weaver, S. J., Dy, S. M., \& Rosen, M. A. (2014). Team-training in healthcare: a narrative synthesis of the literature. BMJ Quality \& Safety, 23(5), 359-372. https://doi.org/10.1136/bmjqs-2013-001848

Weber, M. (1947). The theory of social and economic organizations. New York: Free Press.

West, M. A., Borril, C. S., Dawson, J. F., Brodbeck, F., Shapiro, D. A., \& Haward, B. (2003). Leadership clarity and team innovation in healthcare. The Leadership Quarterly, 14(4-5), 393-410. https://doi.org/10.1016/S1048-9843(03)00044-4

West, M. A., Guthrie, J. P., Dawson, J. F., Borrill, C. S., \& Carter, M. (2006). Reducing Patient Mortality in Hospitals: The Role of Human Resource Management. Journal of Organizational Behavior, 27(7), 983-1002. https://doi.org/10.1002/job.396

Wilson, V. J., McCormack, B. G., \& Ives, G. (2005). Understanding the workplace culture of a special care nursery. Journal of Advanced Nursing, 50(1), 27-38. https://doi.org/10.1111/j.1365-2648.2004.03346.x

Wu, Q., Cormican, K., \& Chen, G. (2018), A Meta-Analysis of Shared Leadership: Antecedents, Consequences, and Moderators. Journal of Leadership \& Organizational Sudies, first online. https://doi.org/10.1177/1548051818820862

Yukl, G. A. (1998). Leadership in organizations (4th ed.). Englewood Cliffs, NJ: Prentice Hall. 
Zhu, J., Liao, Z., Yam, K. C., \& Johnson, R. E. (2018). Shared leadership: A state-of-the-art review and future research agenda. Journal of Organizational Behavior, 39(7), 834-852. https://doi.org/10.1002/job.2296

Zaccaro, S. J., Heinen, B., \& Shuffler, M. (2009). Team Leadership and Team Effectiveness. In Salas, E. Goodwin, G.F., \& Burke, S. (Eds), Team Effectiveness in Complex Organizations: Cross-Disciplinary Perspectives pp. (83-111). New York: Routledge.

Zwartjes, M., Van Langenhove, L., Kingah, S. \& Maes, L. (2012). Determinants of regional leadership: is the European Union a leading regional actor in peace and security?. Southeast European and Black Sea Studies, 12(3), 393-405. https://doi.org/10.1080/14683857.2012.711093

\section{Note}

Note 1 . See also the representative definitions of shared leadership reported in the recent article of Zhu et al. (2018, p. 836).

\section{Copyrights}

Copyright for this article is retained by the author(s), with first publication rights granted to the journal.

This is an open-access article distributed under the terms and conditions of the Creative Commons Attribution license (http://creativecommons.org/licenses/by/4.0/). 